\begin{tabular}{llllllll}
$\mathbf{A}$ & $\mathbf{R}$ & $\mathbf{T}$ & $\mathbf{Y}$ & $\mathbf{K}$ & $\mathbf{U}$ & $\mathbf{L}$ & $\mathbf{Y}$ \\
\hline
\end{tabular}

ROCZNIKI FILOZOFICZNE

Tom LXIX, numer $4-2021$

DOI: http://doi.org/10.18290/rf21694-1

GRZEGORZ P.KARWASZ

\title{
ON DETERMINISM, CAUSALITY, AND FREE WILL: CONTRIBUTION FROM PHYSICS
}

\section{INTRODUCTION}

Determinism, causality, chance, free will and divine providence form a class of interlaced problems lying in three domains: philosophy, theology, and physics. ${ }^{1}$ Dariusz Lukasiewicz in recent issue of Roczniki Filozoficzne opened a discussion on chance in nature and compatibility of such chance with divine providence. He writes in the introduction: "Contemporary science is the best source of knowledge available to us about the world we live in" (LUKASIEWICZ 2020, 5). Physics - that starting from Copernicus, Kepler, Galileo and Newton, with its deductive theories and the paradigm of repeatable experiments is a prototype par excellence of natural sciences. Nature became mathematical and predictable with Newtonian physics. Robert Crease, physicist and philosopher writes in Physics World (CREASE 2013, 25) on the caesura between pre- and post-Newtonian science: "The arrival of the Newtonian universe was attractive, liberating and even comforting to many of those in the 17 th and 18 th centuries; its promise was that the world was not the chaotic, confusing and threatening place it seemed to be ruled by occult powers and full of enigmatic events - but was simple, elegant and intelligible."

Prof. Dr. habil. Eng. Grzegorz P. Karwasz - Nicolaus Copernicus University (UMK), Faculty of Physics, Astronomy and Applied Computer Science, Institute of Physics, Department of Physics Didactics; correspondence address: ul. Grudziądzka 5/7, 87-100 Toruń; e-mail: karwasz@fizyka.umk.pl; ORCID: https://orcid.org/0000-0001-7090-3123.

1 "Questions focusing on the relationship between human freedom and determinism have been at the forefront of philosophy for the last three hundred years and the contemporary debates about divine action an science owe an often silent dept to this pedigree" (SAUNDERS 2002, 44). 
On the other hand, the rigid mathematical laws of physics bring a mental temptation for full, materialistic determinism. Simplifying Laplace's quotation, ${ }^{2}$ the universe needed no more God's intervening. Quantum physics, brought a kind of sigh for indeterminism: Schrödinger's cat can be half alive and half dead. This interpretation is an oversimplification: the cat is (potentially) both dead and alive only until we check it. Terms like "instant collapse of the wave function" or "quantum decoherence" are used for such a passage from a hypothetical (but not provable) "superposition" of mathematical states to an observable state. As we discuss in the first, physical part, it can rather happen that also quantum physics is fully deterministic: the flight path of a single electron is impossible to be predicted (for us), but it does not mean that it is chaotic.

The escape-lane from plain determinism, are so-called contingent events: chance, that serves in physics, ${ }^{3}$ in human lives and, maybe, as suggests Łukasiewicz, also in divine action. The statement that chance can be a part of divine providence was criticized by Thomas Flint who points out, among others, to unclear significance of "chance" - no detectable cause. "Detectable for whom? For one of us, mere mortals? For God?" (FLINT 2020, 56). Flint's question clearly separates an ontological indeterminism/ determinism from the epistemic one. The questions of determinism and causality, outside the mere physics are discussed in the second part of the paper.

The question of free will is discussed in third paragraph. In particular the solution of antinomy between (deterministic) physics and free will, given by Planck is resumed. I do not share his opinion, as his reasoning was limited to the material world. I argue that we, humans, may influence the deterministic chains of events via "short-cuts" through immaterial world. Something similar as Einstein (1935) conceived for space-time tunnels.

We conclude, as an experimental physicist, that a dualistic, material + immaterial view of the world, allows to collocate together the strict determinism from physics, the broader-term of causality that holds also in nonmaterial actions, the human free will which can overcome the determinism, and divine providence, limited neither by space nor time.

\footnotetext{
${ }^{2}$ Usually the phrase attributed to Laplace is: "I need not the hypothesis of God". This is, as results from detailed discussion on Wikipedia, an oversimplification. Either it was pronounced by Napoleon, or it is a shortened version of Laplace's statement, as reported by English astronomer, William Herschel: "De la Place wished to shew that a chain of natural causes would account for the construction and preservation of the wonderful system". https://en.wikipedia.org/wiki/PierreSimon_Laplace (accessed 06/11/2020).

${ }^{3}$ Note a precise distinction between a mere, ungovernable chance and the scientific probability underlined by Mariusz Grabowski in the recent issue of $R F$ (GraBowsKi 2020).
} 
A hidden (but not much) assumptions of the whole discussion are the existence of God and His action in the world, by Him created. But we begin from physics.

\section{DETERMINISM IN PHYSICS}

Modern physics, with quantum mechanics and Einstein's theory of relativity influenced not only contemporary science and philosophy but also theology. Unpredictability of events due to Heisenberg's principle, the lack of any universal time, quantum and classical "chaos," self-emerging of order from this chaos - are invoked in many different contexts. This leads to great debates in which new definitions of old philosophical categories like causality (BRukner 2018), determinism (Doboszewski 2019; MÜller 2018) or completely new concepts like quantum causation (SHRAPNEL 2019), non-local causality, retro-causality (CAVALCANTI 2010) are proposed. Open questions of modern physics serve also as backbones in theological reviews, see for ex. (Rolson 2014; Del Carril 2018).

Physicists practice discussions on their own: with the centenary of Bohr's model of hydrogen atom prestigious journals, Physics World and Nature devoted special issues to open questions of quantum mechanics. From questionnaires answered by the most influential quantum physicists, it emerged that opinions on determinism and ontological realism in the quantum world were strongly polarized (SCHLOSSHAUER 2013):

The respondents were sharply divided on questions that Bohr and Einstein quarreled about. For example, when we asked whether the physical properties of objects are well defined before these properties are actually measured, half of the respondents said that sometimes they were, while the other half answered with a categorical "no." And when we asked how best to interpret the wave functions that physicists use to calculate the probabilities of their measurement results, a quarter of respondents said the wave function are something akin to a physical property. A quarter said they are merely a representation of what we know about the object, while a third preferred a mixture of the two options.

Already mentioned Robert Crease wrote in Philosophy of Physics: "Quantum mechanics is indeed difficult to interpret" (CREASE 2017, 11). The very founders of quantum mechanics, Max Planck, David Bohm, Pascual Jordan searched solutions and/or interpretations to preserve "a classical," i.e. 
point-by-point determinism: hidden variables, pilot wave functions, non local potentials etc., see (Planck 1932; Bohm 1980; BeneduCI 2013). These proposals have not gained acceptance of the majority of scientists, who are inclined towards a probabilistic vision of the micro-world, sometimes denying even the objective realism. "The realist would say the Mont Blanc has a height and this is independent of any human being actually measuring it" - comments Italian nuclear physicist, Marco Giammarchi $(2015,155)$ "but in quantum mechanics it seems different."

As an experimental physicist I strongly support the realism of nature, its understandability, and strict correspondence between "quantum" and "classical" worlds (KARWASZ 2005). And physics is rather rigid about the determinism: the now-and-here defines univocally the later-and-further. Even more, as writes Tim Maudlin $(2007,168)$, this is the "entire back light-cone of an event (or even the entire antecedent stage of the world in some preferred frame) is the cause of the event, that being the minimum information from which, together with the laws of physics, the event can be predicted."

However, we must distinguish the terms determinism, causality and predictability. ${ }^{4}$ Keeping in mind the whole complexity of modern meaning of these terms (see references above) by determinism we understand that every event had a cause, and by causality that every action may bring a consequence. Thus, the determinism forms a temporal-space chain of events while the causality, in principle, might be non-local. Further, neither the determinism nor causality assure the predictability, even in classical physics, as we discuss it below.

Problems with acknowledging determinism follows from difficulties in deducing the mechanism from observed results. Thomas Flint $(2020,56)$ comments Łukasiewicz's ontological chance in a following way:

An ontological chance, for example, is said to be one for which there is no detectable cause. How, one might wonder, is "detectable" being understood? Detectable for whom? For one of us, mere mortals? For God? And why should the detectability of a cause matter? If there are indeed causes for an event, causes that we (whoever "we" designates) cannot detect, then would it not make more sense to say that the event in question looks to be chance, but actually is not?

\footnotetext{
${ }^{4}$ Tim Maudlin specifies that this determinism is reserved to quasi-Newtonian physics. "If the laws of physics turn out to be quasi-Newtonian, then there could be a fairly rich objective causal structure at the fundamental level." But Maudlin separates mere physics from the principle of causality: "None of this, of course, is of much interest to physics per se, which can get along quite well with just the laws and without any causal locution."
} 
In fact, the ontological determinism of classical physics does not mean any epistemic determinism. Physics, in primis, admits the limits that are put on our knowledge of events. A constant (i.e. limited) velocity of light used as a postulate (and the result) of the special relativity sets limits on the external dimensions of the universe cognizable to us; quantified (i.e. above zero) energies and momenta of electrons, neutrinos and photons set limits on the minimal precision of measurements, and therefore also on the predictions in the micro-world. This does not mean that any of electrons wander casually in an atom: orbits in hydrogen atom are precisely determined as probabilities resulting from the analytical solution of Schrödinger's equation. These probabilities do not change nor are "chaotic." Otherwise the whole matter would disintegrate in a second. The limits of predictability are epistemic, i.e. independent of the experimental technique. Both calculations and experiments (ItATANi 2004) give a kind of "cloud" in the space where atomic electrons may be found. And this is both a fixed, mathematical picture and a real, experimental object.

On the other hand, also classical physics, even if no doubts exist on its ontological determinism, is not epistemically deterministic. In order to predict events, the detailed knowledge on neighbouring objects in the past space-time cone is necessary. Say, we are not able to predict impacts of great meteors on Earths, in spite of great observational efforts: too many celestian bodies orbit around Sun and too many (gravitational) interactions should be taken into account in calculation. More, the physical limits of processing information (i.e. the memory space of computers) render impossible "exact" solutions. From these limits terms like "classical chaos" arise: it has nothing to do with Greek meaning of chaos and reflects solely the ultra-high sensibility of solutions on the choice of initial parameters in the numerical procedures.

Quantum physics is epistemically indeterministic also for deeper reasons. Łukasiewicz $(2020,17)$ says: "The key idea of epistemic deism is that God acts causally (intervenes) in the world only at the quantum level of the physical world, which is epistemically inaccessible to our minds; therefore, divine action lies beyond our cognitive grasp." We find two distinct statements here, with different validity.

Sure, the quantum level is epistemically inaccessible to our minds, as states Giammarchi (2015) "another victim of quantum mechanics is pure determinism" and adds "the predictive power about the outcome of a single experiment in generally lost." John Polginghorne, as theoretical physicist 
and theologian writes $(2005,37)$ that from "the discovery of the cloudy fitfulness of quantum theory [...] the future is not already implied by the present." Both statements stress the impossibility of prediction, and Giammarchi adds "from a single experiment."

The very idea of the uncertainty principle came to Heisenberg when he observed the traces of an electron in the fog-camera (Wilson's chamber): only macroscopic water droplets are visible, not an electron. And between these droplets we suppose that the electron has traveled with a given velocity. ${ }^{5}$ But, at the end, we note that all droplets lie on a straight line, see fig. 1a. A posteriori we see the trajectory and single droplets, even if we were not able to predict their positions a priori.

A wave-packet that is used to describe via Schrödinger equation the motion of an electron, dissolves with time, see fig. 1b. But it is not an electron which widens its physical dimensions, but simply the expected position of the electron that extends to a broader range. "Expected" means a real position, but only when the experiment has been done.

It seems that the main problem with "quantum indeterminism" lies in mixing objects that are physical (i.e. material) with concepts like the information that, in principle, can materialized when written down, but per se is immaterial. Is poetry or music material? Notes and printed letters - yes! but mental impressions while listening music — no! Discussing Heisenberg we could also invoke Aristotle's distinction between (immaterial) potentiality and (material) actuality (SILva 2013).

Thus, recently, in spite of quantum mechanics, Laplace's conviction that universe is ontologically deterministic comes back. The novelty of the modern thought is acceptation of the epistemic indeterminism. John Gribbin in Deep Simplicity $(2004,69)$ writes:

This means that a computer with an infinite memory is required to specify the state of a single particle. No computer can be bigger than the entire Universe, and if you define the Universe as 'everything there is,' this means that the only system that can replicate the behaviour of the Universe in every detail is - the Universe itself. Even if, as Laplace thought, the Universe is entirely deterministic and the whole future is contained within its present state, there is no way at all to predict or know the future, except from watching the Universe evolve. Whether or not we have free will, the Universe behaves as if we have free will, which is really all that matters. The Universe is ignorant of its own future, and it its own fastest simulator.

5 "Tatsächlich sieht man ja nur einzelne Wassertröpfchen in der Kammer, die sicher sehr viel ausgedehnter ein als ein Elektron" (HEISENBERG 1969, 108). 
The flight of a bunch electrons through two narrow slits is also governed by a wave-like, Schrödinger equation, giving on the screen an interference pattern and making impossible to determine through which slit a single electron passed, see fig.1c. We can extract this latter information from nature, illuminating electrons by photons before they enter a slit. But then the interference patter disappears and only classical shadows of slits remain. The same holds for photons, which clearly should be treated as waves: labeling photons, in order to trace which slit they used, makes the interference picture disappear ${ }^{6}$. As write authors of such a didactical experiment (Dimitrova 2009), the concept of photon's trajectory looses its sense. It seems that nature intrinsically "protects" its information. The ontology becomes well separated from our epistemic possibilities.

The second part of the above quoted sentence by Łukaszewicz that "God acts causally (intervenes) in the world only at the quantum level" is a kind of mental short-cut. We will discuss the "god of quantum gaps" in next paragraph.
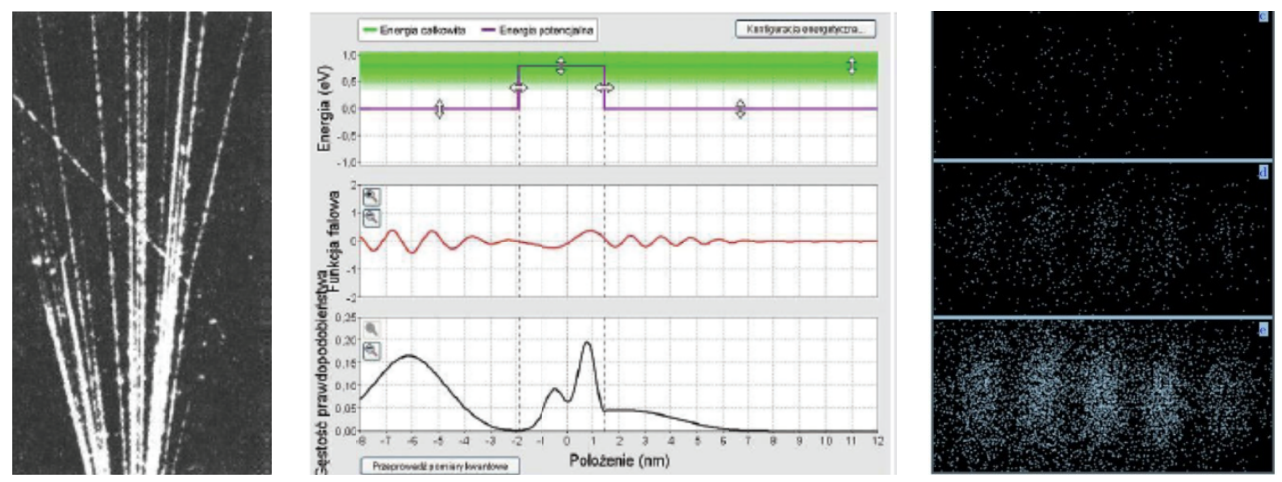

Fig. 1. (a) A picture similar to that which triggered Heisenberg to formulate the principle of indetermination: in a fog chamber we do not see the electron but only water droplets where electron collided with air particles and ionized them, causing the condensation of $\mathrm{H}_{2} \mathrm{O}$ vapour. Electron for sure passed by the positions of the droplets and for sure traveled between the droplets in a given time: we know the position exclusively-or the velocity. But the electron itself "knows" how to collide with air particles; we call the appropriate quantity cross section: a probability of the process. (Alpha particles collision in fog chamber filled with $\mathrm{H}_{2}$. From HAKEN and WoLF).

(b) Simulation of electron wave-function propagation through a barrier, using Schrödinger timedependent equation (total probability, lower curve). This is not that electron is divided into three

\footnotetext{
${ }^{6}$ And further: renouncing the labeling already done the interference patter is restored. The process is called "quantum eraser", see for ex. (Dimitrova 2009).
} 
parts: a measurement done in this particular moment would yield the position of the electron with such a probability. Each next wave-packet launched by the operator of the modeling will yield exactly the same picture. PhET, Colorado University, shot by Author.

(c) Interference pattern of electrons passing through two slits: it is build point by point. Single electrons are point like ("classical" radius $-2.3 \times 10^{-15} \mathrm{~m}$ ): their ensemble gets distributed on the screen to a pattern that is predicted by Schrödinger's equation. Photo from experiment by (BACH et al. 2013)

\section{GOD OF GAPS}

"The laws of the quantum world are, as contemporary science claims, probabilistic $^{7}$ or indeterministic; therefore, there are 'free gaps' not determined by these laws, and thus, there is room for divine action" (LUKASIEWICZ $2020,17)$. The origin of this discussion is the indetermination principle and so-called Copenhagen interpretation ${ }^{8}$ of quantum mechanics: Heisenberg's principle together with Schrödinger's cat, half alive and half dead, seem to return the freedom of the human will. The idea that God "fills-up" gaps (OleKsewicz 2014) of Heisenberg's uncertainties in physical processes appears in writings of both physicists and philosophers. „God interacts by means of quantum measurement process" as Nicholas Saunders $(2002,139)$ resumes such statements. John Barrow, recently mourned theoretical physicist from Oxford, in Essays on Science, Art and Philosophy (1999, 356) says that quantum mechanics leaves space for some divinity:

The game changes if we introduce quantum mechanics into the reality, because the initial conditions of a complex chaotic system are now undetermined in principle, not only in practice. Moreover: a non-eliminable quantum indetermination can emerge very easily and amplified very quickly can reach a significant level on the scale of our everyday experience. There exist, therefore, to all the effects, some aspects of things that are undetermined, through which a divinity could apparently intervene without violating unchangeable laws of the Nature.

\footnotetext{
${ }^{7}$ We recall again Grabowski (2020) that the terms probabilistic or indeterministic are not inter-changeable.

${ }^{8}$ More precisely, out of first interpretations of quantum mechanics, it was that by Schrödinger which led to quantum gaps. He suggested that the wavefunction instantaneously "collapsed" when the electron hit the screen. This would violate the specific relativity constraints. In Copenhagen interpretation, Niels Bohr stated that the locality and causality are mutually exclusive, see detailed discussion by Barrow and Tipler (1986, 459). Experiments confirming the EinsteinRosen-Podolsky "paradox" (see ASPEC 2015) seem to undermine rather the locality than the causality.
} 
Michał Heller, Polish cosmologist and priest asks: "Does God act on the world by quantum indeterminations, dynamic chaos or fixing the initial or border conditions? None of these possibilities can be excluded, but having in mind the temporal character of our scientific theories, it is better to leave the question open." (OleKsowicz 2014). We add, that "fixing the initial conditions" could be claimed "fine tuning" what would correspond to the universe which in principle could run like a clock, i.e. be fully deterministic. But a perfect, long-lived clock would require a Creator, knowing the whole future.

Some thinkers arrive even to deny the very determinism in favour of God's steering "by hand" the course of Universe. Peter Hodgson $(2005,169)$ comments such ideas:

This interpretation implies that God shapes the course of history by continually guiding atomic events within the limits of the Heisenberg uncertainty relations and subject to the overall probability required by quantum mechanics. Whether this conception of God's activity is satisfactory for theologians to consider, but there is an alternative possibility that the universe in fully deterministic system evolving along a unique path in which each event is completely determined by its antecedents.

This proposal raises a number of questions. First, are the minute interventions constrained within the limits of the uncertainty principle to produce the required macroscopic effect? We can imagine God making billions of such minute interventions without any measurable violation of physical laws so that they eventually produce macroscopic effects, though whether thus is consistent with the omnipotence ad dignity of god is another question.

We fully share Hodgson's perplexity: God has much more complex issues in the world that He created than steering paths of single electrons through gaps of Schrödinger's equation. This would depreciate God's attributes.

\section{DETERMINISM VS. FREE WILL}

Max Planck formulated (in 1900) quantum theory, but in its early, nonprobabilistic form. As said before, he tried to defend the deterministic character of quantum physics. He testified his Christian faith even in times of nazism. ${ }^{9}$ A great part of his philosophical book Where science is going (1932) is

\footnotetext{
${ }^{9}$ See his public lecture held in May 1937 ("Vortrag gehalten im Baltikum, Mai 1937”) Religion und Naturwissenschaft (Plank 1937, 8).
} 
devoted to questions of determinism and free will. These two problems one of physics and the second of the anthropology/psychology/ethics - are closely related. Under conditions of determinism and in absence of free will no responsibility would fall onto our actions: no consciousness is needed. Planck $(1932,107)$ states the relation between the determinism and free will ("volition") in the following words:

Moreover, the assumption of an unfailing causal sequence in all happenings is the basis on which our conduct of everyday life is regulated. But, on the other hand, we have our most direct and intimate source of knowledge, which is the human consciousness, telling us that in the last resort our thought and volition are not subject to this causal order. The inner voice of consciousness assures us that any given moment we are capable of willing this or that alternative.

Planck, as we, was convinced on the determinism in the physical world, but for the free will he used psychological arguments. He solved the dilemma in the chapter "The answer of science" (1932): i) we see deterministic chains of events observing the outside world by our mind; ii) but we can not observe our mind, so the line of deterministic events need not to be still valid - our mind may be equipped with free will.

An answer on the determinism in our acts of free will, says Planck, can not be given by us: an observer and the subject can not be the same person. An eye sees everything, apart from itself; we can not observe ourselves as we can not detach from our shade. Only a transcendental observer, says Planck, can judge if our, human thoughts (and decisions) do follow or not a deterministic chain.

If there be a Supreme Wisdom whose celestial nature is infinitely elevated above ours, and who can see every convolution in our brains and hear every pulse beat of each human heart, as a matter of course such a Supreme Wisdom see the succession of cause and effect in everything we do. But this does not in the least invalidate our own sense of responsibility for our own actions. (PlanCK 1932, 164)

Note that a transcendent being as an observer (guardian and so also a guarantor) of our free will would mean that there is no real free will but only an apparent freedom, leaving the problem still unsolved. We propose an alternative solution: the human free will does break the physical chain of events but it can not be considered within the physics world. This is, to some extent, an analogue to the logical paradox of the Athenian liar. As solved by Alfred Tarski (and earlier by Stanisław Leśniewski), such a logical paradox 
can nor be solved within the language in which it is formulated. It can be solved by going beyond, into some meta-language. We need to go beyond physics, to meta-physics, in order to solve the paradox of the human free will, even if it acts in the physical world.

So, our position goes beyond Planck's: we agree on the strict determinism of the physical world (and we are not skeptic about miracles, contrary to Planck), we agree on the free human will, but we do not agree with his explanation. The human will is free not because of the impossibility of observing it from inside of our mind, but because actions of the human mind are positioned just on the bridge between the material and immaterial world. As Aristotle said, "mind is, no doubt, something more divine and impassible" (De Anima, 408b, 30).

Even agnostic scientists admit that the human mind is the most complex structure in the universe and it is self-governed, so it determines own actions. ${ }^{10}$ And this is the consciousness (and immanently included ethics ${ }^{11}$ ) which makes the difference between humans and animals. Planck $(1932,165)$ makes a similar statement: "I might put the matter in another way and say that the freedom of the ego here and now and its independence of the causal chain, is a truth that comes from the immediate dictate of the human consciousness."

Resuming, our position is slightly different from Planck's: yes! a strict determinism acts in the physical world, but the human mind, or more precisely - the human soul belongs to the non-material world, even if it is "anchored" here into a material substrate, i.e. the brain (JAKI 2004). So it is not subject to the physical determinism.

So, we separate the determinism from the causality: the determinism is the feature of the physics, while the meaning of the causality is broader - it includes also human actions, i.e. born in the mind. So we agree fully with the second sentence of Planck's quotation above: we need not a proof of the free will acting, in order to be fully responsible for our actions.

Does our free will interact with the physical determinism? Yes! via an (unidirectional) arrow of time, imposed not by electrodynamics, cosmology or thermo-dynamics but by the causality principle, see Karwasz (2020). Max Planck $(1932,161)$ says:

${ }^{10}$ Compare for example the voice of Włodzisław Duch, Polish quantum physicist and philosopher - declared agnostic (Duch 2017) who shares the astonishment for the human mind with Hungary-born physicist and priest, Stanley L. Jaki (2004).

${ }^{11}$ See for example the monograph Human. The Science Behind What Makes Us Unique by American neurologist Michael Gazzaniga (2008). 
And what holds good for the present moment of our being holds good also for our future conduct in which the influenced of our present ego plays a part. The road to the future always starts in the in the present. It is, here and now, part and parcel of the ego. And for that reason the individual can never consider his own future purely and exclusively from the causal standpoint.

Belonging to the immaterial world (see KARWASz 2018), the human anima is not any more subject to the physical determinism; but it is still the source of causality. Our possibility to influence the future (not only ours), and the conviction on such a possibility, is "one of the richest sources of inspiration that human being finds", concludes Max Planck.

\section{IMMATERIAL CAUSALITY}

Having described our two pillars - on strict determinism in physics and on the human free will which derives from the immateriality of "anima" and influences the physical word, a corollary question appears: does the causality principle extend beyond the material interactions ${ }^{12}$ ? Believing in prayer and in saint's presence we would admit it. Let's proceed with reasoning, now outside physics.

Speaking about the immaterial human anima we should respond the question: does anything really exist outside/apart the material world? A useful distinction, between physics that treats objects that are material and inserted into space, mathematics that treats objects that may be material but need not be material, and theology which concerns objects eternal, non material and non immersed into space (and time) was settled by Aristotle in Metaphysics (Book VI, 1028a 6-21).

The Bible says that God created "earth" and "heavens." "Earth", that nominated in the first sentence of Genesis would correspond to some primordial forms of matter. And "heavens"? Do they bridge in any way with the matter? And if God exists outside time, as stated by St. Augustin, so future, past and present are contemporary in His mind? So, what will happen in the future, has already happened in God's mind? Again the same questions, now arising not from the physical determinism but from outsidetime-and-space metaphysics: do we influence the course of the universe or is

\footnotetext{
${ }^{12}$ We are aware of Polkinghorne's opinion "that our actual knowledge of the causal structure of the physical world is still patchy and incomplete" (Polkinghorne 2005, xii). But to the same measure, we have no indications for physical phenomena occurring without a cause.
} 
it already fixed? The question is even more acute if we recall God's attributes - omnipotence and omniscience, from Newton's Scholium Generale (1713).

The best text to explain the interplay between almighty God and its creation is the Catechism of Catholic Church (1992), art. 302:

Creation has its own goodness and proper perfection, but it did not spring forth complete from the hands of the Creator. the universe was created "in a state of journeying" (in statu viae) toward an ultimate perfection yet to be attained, to which God has destined it. We call "divine providence" the dispositions by which God guides his creation toward this perfection: By his providence God protects and governs all things which he has made, "reaching mightily from one end of the earth to the other, and ordering all things well." For "all are open and laid bare to his eyes," even those things which are yet to come into existence through the free action of creatures.

Thus, in the interplay: physical determinism $\leftrightarrow$ metaphysical principle of causality $\leftrightarrow$ human free will, we should include also divine providence. It is not His intervening in gaps of quantum world but His dialoguing with his all creatures, including the last, i.e. "very good" (Genesis) one. Thomas Aquinas discussed this question in detail. Ignacio Silva (2019) writes "Aquinas affirms that God, as primary cause of every being's existence, is also the cause of the causal power of that being and of the action of that being." But God tries to influence the free will acts of his creatures, preventing them from actions that do not lead to a beneficial end. This is God's providence. As writes Piotr Roszak (2017):

Providence in Thomistic perspective is characterized by directness and includes all beings, even the least significant. In contrast, governing the world is not executed directly, but by means of secondary causes. Everything that has been created is subjected to Divine Providence, which is mainly related to two attributes: the wisdom and power. As we can see, for Aquinas the perspective of the debate on Providence is twofold: providentia is applied both to general and particular order of things, in universali and in singulari. According to him the contingency, free will, fortune and chance are 'dimension' (or framework), through which providence acts.

May a immaterial action, like a mere thought or a prayer cause a material effect? May be... 


\section{DIVINE ACTION}

Now we come to the last point raised by Łukaszewicz: Christian (or better: Jewish) theology insists not only on the determinism, but on the already-done determinism, i.e. God who is outside time and space and therefore knows not only the past but also the future, which is (for Him) already concluded. Re-quoting from Łukasiewicz $(2020,8)$ :

For you have done these things and those that went before and those that followed. You have designed the things that are now, and those that are to come. What you had in mind has happened; the things you decided on presented themselves and said, "Here we are!" For all your ways are prepared in advance, and your judgment is with foreknowledge. (Judith 9:5-6, emphasis by author)

God needs not to intervene in quantum gaps; in reality He also needs not to shape the "ball" of the Universe, see fig. 2a. One could state that all the history and the future of the Universe is ascribed to the laws of Physics, that are unchangeable from 13.78 billion years (we know it analyzing the spectra of the most distant, in space and time, stars). But as said Georges Lemaitre (1931), who first postulated the expansion of the Universe, it is impossible that the whole future was contained in a single, primordial atom. God intervenes in many modes.

Łukasiewicz underlines God's omnipotence, and supports this attribute by the fact that "...God created the world without any meticulous plan, because he did not need such a plan" (p. 29). This statement has been contested both by Flint (p. 60) and by Hasker (2020). The latter opposed two ways of constructing a medieval village - with a well defined plan and in a "evolutive" way, but by skillful and motivated habitants. No divine plan would reflect in a try-and-error history of the universe. But it does not seem be the casethe whole line of events in the cooling down universe - separation of matter and radiation (270 kyrs after Big Bang), formation of stars (180 Myrs after), their evolution, explosions, formation of planets (Earth 4.567 Myrs ago) and subsequent cooling down of Earth are all unidirectional and brought in a possibly quickest way to the appearance of Homo sapiens. More, the Logos, "existing in the beginning", can be understand in a theological manner but also a philosophical one. In fig. $2 b$ we show the imagination of a Medieval artist how it happened.

In the theme of divine action a comprehensive review was done recently by Henry and Tabaczek (2017). They, after Michael Dodds, enumerate four, 
apart from deism, theological schools: from the breaker of natural laws (divine interventionism), to God that acts exclusively via "the realm of personal, existential encounter" (liberal theology), and God self-limited "who respects the intrinsic nature of the world that is his own creation."

In spite of being an experimental physicist, the closest to us is the process theology that says that God could intervene directly, both on nature and on humans, but with us uses rather a persuasion, allowing in this way also the existence of evil.

Although God is present in the process of actualization of each actual occasion (momentary events constituting reality), his action is limited to inviting and persuading them to perceive eternal ideas in their coming to be. He is thus trying to direct the future of the world toward its perfect realization. However, his persuasion may be rejected by actual occasions, which explains the presence of evil in the world. God himself is not fully personal and realized in his primordial nature. This lack of perfection is overcome only in God's consequent nature in which he is changed by his relation to the world, which finds in turn its objective eternity in God. (HeNRY 2017, 286)

God may intervene in (His) material and immaterial world in any moment He wants - in this we would agree with interventionists. But "may" does not mean "must." For "everyday" operation immutable and fixed at the very beginning ${ }^{13}$ physical laws are sufficient. And human free will, possible enlightened by the divine grace is an equally strong "lever" of divine action in the world.

Finally, we discuss the antinomy between God's omniscience- "God's knowledge of all events from eternity" (HASKER 2020) and the possibility to change the deterministic chain of events by human action, his/her thought, his/ her prayer. This is just because God's omnipotence: it is within His governance to allow the change of what otherwise would have been already happened. "Æternus est \& infinitus, omnipotens \& omnisciens", quoting Newton's Scholium Generale. God's complementary attributes seem to be contradictory? A paradox? Maybe, but physics is full of them.

${ }^{13}$ Paul A. M. Dirac, author of the relativistic version of quantum mechanics lunched a vague idea that physical constants could mutate with the evolution of the universe. But he was wrong. The inviolable limit of the velocity of light allows us to scrutinize emission spectra of stars distant from now-and-here by almost 13 bln years: the hydrogen (and helium) lines are exactly the same like at present. 

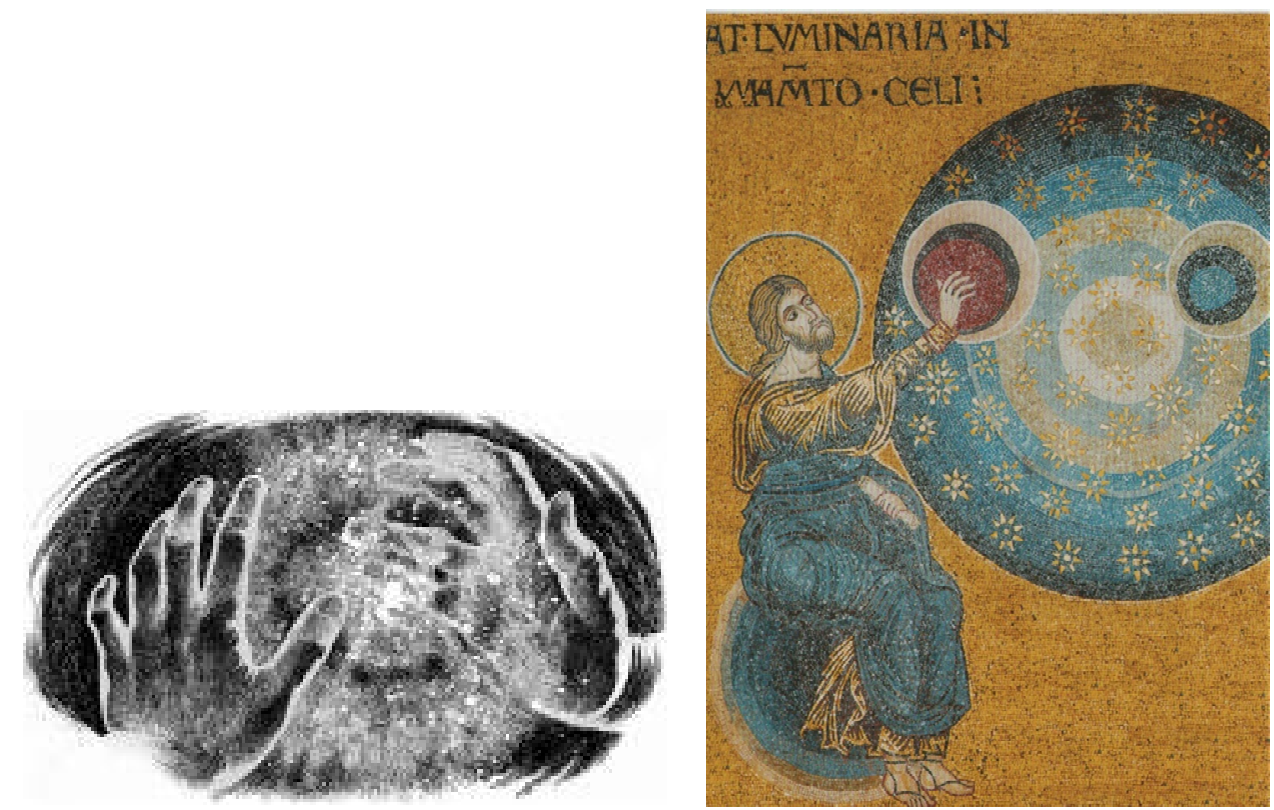

Fig. 2. (a) "Fingers of God" - a sketch used by English-language Wikipedia in 2011 (now removed) to explain a cosmological effect called "Redshift-space_distortion." Presently, scientists miss any explanation for the mysterious dark energy that makes the Universe to expand and in this way protecting it from an immediate gravitational collapse. We are not able to explain why this expansion accelerates, either.

(b) God, young and smiling creates the World sitting comfortably and grasping a technical drawing: not thunders and clouds like we remember from times of Michelangelo. Joking, the medieval artist knew also Copernicus's system: Venus, bluish (on NASA pictures), rotates around Sun on a closer orbit than reddish Mars (?) (Cattedrale Monreale, Sicily, 13th century).

\section{CONCLUSION}

Physics, including quantum mechanics, bring arguments for a strict ontological determinism, within its domain, i.e. the material world. On the other hand, physics, especially the relativity and quantum mechanics, excludes our (i.e. human) epistemic omnipotence. The determinism need not to hold in (a possible) immaterial world, but the causality - yes! in both worlds.

As compared to determinism, the causality principle is a broader term: no phenomena in physics, including the relativity, quantum physics, "teleportation" etc. do indicate that the causality could be broken. We argue that the causality extends also to the immaterial world, and to "bridges" between the two worlds. The possibility that the human anima may act also via 
immaterial causality would bring "humankind in his image, in the image of God." With all ethic responsibility for our actions.

God need not, even if $\mathrm{He}$ can, intervene in quantum gaps, weather changes or earthquakes. He (usually) leaves the laws of nature act autonomously. His main link to His Universe is Man (and Woman) as, probably unique apart from angels, secondary cause. God leaves not only autonomy, but full freedom - of acting and thinking - to His Creatures.

The free will is the key factor in performing this function by man. Therefore, even Planck undertook the discussion. To us, the human free will does not result from some "quantum brain" or neurons that go with their own scenarios. The free will comes from the very nature of the human soul, that, even according to Aristotle, "has some of the divine": the human sole belongs to the immaterial world, even if one can not prove it in terms of repeatable, physics-like experiments. Separating arguments of physics, the free will and Divine Providence assures to these subjects their autonomous spaces.

Resuming my comment to Łukasiewicz (2020) - even if we differ substantially in the use of arguments from physics, we agree about his final conclusions (reported also by Hasker) on God's attributes, as listed by Newton in his Natural Philosophy: eternal, infinite, omniscient, omnipotent.

\section{REFERENCES}

Aristotle. 1924. Metaphysics. Translated by William David Ross. Oxford: Clarendon Press.

AsPeC, Alain. 2015. “Closing the Door on Einsteins and Bohr's Quantum Debate." Physics 8: 123. https://physics.aps.org/articles/v8/123. Accessed 7.11.2020.

Bach, Roger; Damian Pope, Sy-Hwang Liou, Herman BatelaAn. 2013. "Controlled double-slit electron diffraction." New Journal of Physics 15: 033018.

Barrow, John D. 1990. Between Inner Space and Outer Space. Essays on science, art and philosophy. Oxford: Oxford University Press.

BArrow, John D., and Frank J. TiPLER. 1986. The Anthropic Cosmological Principle. Oxford: Oxford University Press.

Bонм, David. 1980. Wholeness and the Implicate Order. London: Routledge \& Kegan.

Beneduci, R., and Franklin E. Schroeck, Jr. 2013. "On the Unavoidability of the Interpretations of Quantum Mechanics." American Journal of Physics 82: 80.

Brukner, Časlav. 2018. "Causality in a quantum world." Physics Today, 28 March 2018. DOI: 10.1063/PT.6.1.20180328a.

Catechism of the Catholic Church. 1993. Holy See. https://www.vatican.va/archive/ENG0015/ P19.HTM. Accessed 7.11.2020. 
Cavalcanti, Eric G. 2010. “Causation, Decision Theory and Bell's Theorem: A Quantum Analogue of the Newcomb Problem." The British Journal for the Philosophy of Science 62: 569-97.

Crease, Robert B. 2017. Philosophy of Physics. Bristol: IOP Publishing.

Crease, Robert P. 2013. "Critical Point. The quantum moment." Physics World 26, no. 3: 25-7.

Del CARril, Ignacio Enrico. 2018. "La física cuántica y el diálogo con la religión." Scientia et Fides 6: 9-29.

Doboszewski, Juliusz. 2019. "Relativistic spacetimes and definitions of determinism." European Journal for Philosophy of Science 9: 24 (14 pp.). DOI: 10.1007/s13194-019-0248-6.

Dimitrova, T. L., and A. Weiss. 2009. "A portable double-slit quantum eraser with individual photons." Physica Scripta, 135: 014003.

Duch, Włodzisław. 2017. "Why minds cannot be received but are created by brains." Scientia et Fides 5 (2): 195.

Einstein, Albert, and Natal Rosen. 1935. "The Particle Problem in the General Theory of Relativity", Physical Review 48: 73-7.

FLINT, Thomas P. 2020. "Providence, chance, divine causation and Molinism: A reply to Łukasiewicz." Roczniki Filozoficzne 68, no. 3: 56-9.

Fuller, Robert W., and John A. Wheeler. 1962 "Causality and Multiply-Connected SpaceTime." Physical Review 128: 919.

Gazzaniga, Michael S. 2008. Human: The Science Behind What Makes Us Unique. New York/ Toronto et al.: Harper-Collins.

Giammarchi, Marco G. 2015. "Elementary philosophical and theological consequences of quantum mechanics." European Journal of Science and Theology 11 (3): 155-163.

Grabowski, Marian. 2020. "Is probabilistic theism e tenable idea? Critical remarks on Opatrzność Boża, wolność, przypadek by Dariusz Łukaszewicz." Roczniki Filozoficzne 68, no. 3: 205-240.

GribiIn, John. 2004. Deep Simplicity. London: Penguin Books.

Guth, Allan H. 1981. "Inflationary universe: A possible solution to the horizon and flatness problems." Physical Review D, 23, no. 2: 347.

Haken, Hermann, and Hans Christophor Wolf. 2005. The Physics of Atoms and Quanta. Introduction to Experiments and Theory. 7th ed. Berlin: Springer.

Hasker, William. 2020. "How to make a world." Roczniki Filozoficzne 68, no 3: 35-53.

HeISEnBerg, Werner. 1969. Die Teil und das Ganze: Gespräche im Umkreis der Atomphysik. München: Piper Verlag.

Henry, John, and Mariusz TABaczek. 2017. "Causation.” In Science and Religion: A Historical Introduction, edited by Gary B. Ferngren, 377-394. Baltimore: Johns Hopkins University.

Hodgson, Peter E. 2005. Theology and Modern Physics. Farnham: Ashgate Publishing.

Itatani, Jiri, J. Levesque, Dirk Zeidler, Hiromichi Nikura, Nenri Pépin, Jean Claude KiefFer, P. B. Corkum and D. M. Villaneuve. 2004. "Tomographic imaging of molecular orbitals." Nature 432: 867-971.

JAKI, Stanley L. 2004. The Brain-Mind Unity: The Strangers Difference. Pinckney: Real View Books.

Karwasz, Grzegorz P. 2006. "On positron scattering on He (and Ar) at low energies.” The European Physical Journal D 37: 153-154. 
Karwasz, Grzegorz P. 2018. "Aristotle's three souls in modern science: re-reading De Anima." Cauriensia 13: 429-458.

Karwasz, Grzegorz P. 2020. "Between Physics and Metaphysics - on Determinism, Arrow of Time and Causality." Philosophy and Cosmology 24: 15-28.

Lemaître, George. 1931. "The Beginning of the World from the Point of View of Quantum Theory." Nature 127: 706. DOI: 10.1038/127706b.

ŁUKASIEWCZ, Dariusz. 2020. "Divine providence and chance in the world." Roczniki Filozoficzne 68, no. 3: 5-34.

Maudlin, Tim. 2007. The Metaphysics Within Physics. Oxford: Oxford University Press.

Müller, Thomas, and Tomasz PlaceK. 2018. "Defining Determnism." The British Journal for the Philosophy of Science, 69, no. 1: 215-252. DOI: 10.1093/bjps/axv049.

Newton, Isaac. 1713. "Scholium Generale." In Philosophice Naturalis Principia Mathematica, 2nd Edition. Cantabrigiæ: Benthley.

Oleksowicz, Marian. 2014. "Discussion about the argument 'God of gaps'." Scientia et Fides 2, no 1: 99-123.

Planck, Max. 1932. Where science is going? New York: W.W. Norton \& Company.

PlanCK, Max. 1937. "Religion und Naturwissenschaft. Vortrag gehalten im Baltikum (Mai 1937) von Prof. Dr. Max Planck (1858-1947), Professor der Theoretischen Physik an der Universität Berlin. Kopie der zweiten unveränderten Auflage 1938 im Johann-AmbrosiusBarth-Verlag/Leipzig erschienen.” Accessed 12.11.2021. https://psychomedizin.com/ medien/ pdf/max-planck.pdf.

Polkinghorne, John C. 2005. Science and Providence. God's interaction with the World, Philadelphia and London: Templeton Foundation Press.

Rolson, Holmes III. 2014. "Creative Genesis. Escalating Naturalism and Beyond." Philosophy Theology and the Sciences 1, no 1: 9-35. DOI: 10.1628/219728314X13946985796871.

RosZAK, Piotr. 2017. "Analogical understanding of divine causality in Thomas Aquinas." European Journal for Philosophy of Religion, 9, no. 4: 1-22. DOI: 10.24204/EJPR.V9I4.1789.

SAunders, Nicolas. 2002. Divine Action \& Modern Science. Cambridge: Cambridge University Press.

Schlosshauer, Maximilian. 2013. "Agreeing to disagree.” Physics World, 26 (3): 28.

SCHroER, Bert. 2011. „Pascual Jordan's legacy and the ongoing research in quantum field theory." European Physical Journal H 35, no. 4: 377-434. DOI:10.1140/epjh/e201110015-8.

Shrapnel, Sally. 2017. "Discovering Quantum Causal Models." The British Journal for the Philosophy of Science 70, no. 1: 1-35.

Silva, Ignacio. 2013. "Werner Heisenberg and Thomas Aquinas on Natural Indeterminism." New Blackfriars 94 (1054): 635-653. DOI:10.1111/nbfr.12036

Silva, Ignacio. 2019. “Aquinas and the Metaphysics of Divine Providence." Filosofía y Teología 22 (43): 53-72. 


\title{
ON DETERMINISM, CAUSALITY, AND FREE WILL: CONTRIBUTION FROM PHYSICS
}

\begin{abstract}
S u m m a ry
Determinism, causality, chance, free will and divine providence form a class of interlaced problems lying in three domains: philosophy, theology, and physics. Recent article by Dariusz Łukasiewicz in Roczniki Filozoficzne (no. 3, 2020) is a great example. Classical physics, that of Newton and Laplace, may lead to deism: God created the world, but then it goes like a mechanical clock. Quantum mechanics brought some "hope" for a rather naïve theology: God acts in gaps between quanta of indetermination. Obviously, any strict determinism jeopardizes the existence of free will. Yes, but only if human mind follows the laws of physics and only if nothing exists outside the physical limits of space and time. We argue that human action lies in-between two worlds: "earth" and "heavens" using the language of Genesis. In that immaterial world, outside time and space constraints, there is no place for the chain of deterministic events. We discuss, in turn, that the principle of causality, a superior law even in physics, reigns also in the non-material world. Though, determinism in the material universe and causality in both worlds seem to be sufficient conditions, to eliminate "chaotic", or probabilistic causes from human (and divine) action.
\end{abstract}

Keywords: causality; determinism; quantum physics; classical physics; free will.

\section{O DETERMINIZMIE, PRZYCZYNOWOŚCI I WOLNEJ WOLI: WKŁAD FIZYKI}

\section{Streszczenie}

Determinizm, przyczynowość, przypadek, wolna wola i Boska opatrzność stanowią klasyczny, splątany problem, leżący w trzech domenach: filozofii, teologii i fizyki. Niedawny artykuł Dariusza Łukaszewicza w Rocznikach Filozoficznych (nr 3 z 2020 r.) jest tego znakomitym przykładem. Klasyczna fizyka, ta Newtona i Laplace'a, może prowadzić do deizmu: Bóg stworzył świat, ale ten działa sam, jak mechaniczny zegarek. Fizyka kwantowa przyniosła pewną „nadzieję” dla raczej naiwnej teologii: Bóg działa w lukach między kwantami nieoznaczoności. Oczywiście, ścisły determinizm zagrażałby istnieniu wolnej woli. Tak, ale tylko wówczas, gdyby ludzki umysł był rządzony tylko prawami fizyki i gdyby nic nie istniało poza fizycznymi granicami czasu i przestrzeni. Dyskutujemy, że ludzkie działania leży pomiędzy dwoma światami: „ziemią” i „niebem”, używając języka Księgi Rodzaju. W świecie niematerialnym, poza ograniczeniami czasu i przestrzeni, zdarzenia deterministyczne nie stanowią sekwencyjnego łańcucha. Dyskutujemy natomiast, że zasada przyczynowości, prawo nadrzędne nawet dla fizyki, rządzi również w świecie niematerialnym. Tak więc, determinizm w świecie materialnym i przyczynowość w obu światach wydają się być warunkami dostatecznymi, aby wyeliminować „chaotyczne" czy przypadłościowe przyczyny ludzkiego (i Boskiego) działania.

Słowa kluczowe: przyczynowość; determinizm; fizyka kwantowa; fizyka klasyczna; wolna wola.

Informacje o Autorze: Prof. dr hab. inż. GRZEGORZ P. KARWASZ - Uniwersytet Mikołaja Kopernika (UMK), Wydział Fizyki, Astronomii i Informatyki Stosowanej, Instytut Fizyki, Zakład Dydaktyki Fizyki; adres do korespondencji:ul. Grudziądzka 5/7, 87100 Toruń; e-mail: karwasz@ fizyka.umk.pl; ORCID: https://orcid.org/0000-0001-7090-3123. 